\title{
Cashing Out, Cashing In: rural change on the south coast of Western Australia
}

\author{
GEORGE N. CURRY, GINA KOCZBERSKI \& JOHN SELWOOD, Curtin
}

University of Technology, Australia; University of Winnipeg, Canada

\begin{abstract}
Over the past century the cultural and physical landscape of the Shire of Denmark on the south coast of Western Australia has been transformed by successive waves of in-migrants. The paper examines the period since the early 1970s when alternative lifestylers and early retirees, attracted by the district's natural beauty and low land prices, began moving in and acquiring former Group Settlement holdings. The activities of these and subsequent 'alternatives' and 'cashed out' early retirees settling in the district have raised the marketability of the Shire's cultural capital. These changes have occurred in association with broader processes of rural restructuring and changing notions of 'rurality'. Increasingly, Denmark's cultural and physical landscape has become a highly marketable product for consumption by Perth's affluent middle classes. In recent years land prices have risen rapidly as speculators and financiers seek to 'cash in' on the 'cashed out' society. The paper explores these issues and relates them to broader processes of economic and social change occurring at the national and international levels.
\end{abstract}

KEY WORDS Western Australia; rural geography; structuration theory; rural restructuring; internal migration.

\section{Introduction}

Processes of internationalisation, globalisation, and economic restructuring along with technological and demographic changes are transforming rural Australia. In the postwar period many areas of rural Australia experienced rural out-migration (Hugo 1994; Hugo \& Smailes 1985; McKenzie 1994) as farm amalgamations, capital-intensive production and declining terms of trade led to falling employment opportunities in rural areas. While many inland dry-farming areas continue to experience depopulation, there has been a reversal of these population trends in select rural areas. Rural areas experiencing population growth and in-migration are close to large metropolitan areas, possess attractive, scenic environments (e.g. coastal, riverfront, mountainous area), or show tourist potential (Hugo 1994, p. 15; see also Sant \& Simons 1993; Walmsley et al. 1998). In addition, such environments become a favoured target for holidaymaking, second homes and, ultimately, as outliers of permanent residence forming part of a wider urban field. The study of this phenomenon is now extensive with comparative material available from a variety of international sources (e.g. Coppock 1977; Bryant et 
al. 1982; Dilley 1993; Frey 1993; Halfacree 1994; Murdoch \& Marsden 1994; Stadel \& Selwood 1996; Ilbery 1997).

While much has been written on the impact of macro-economic trends on rural areas of the industrialised world, until recently relatively little attention has been paid to the interaction of local agency with macro-economic forces in processes of rural transformation. Some rural geographers have begun to emphasise the role of individuals and groups in stimulating or constraining change at the local level, and, importantly, how these endogenous factors interact with wider forces for change (e.g. Murdoch \& Marsden 1994; Marsden 1996; Marsden et al. 1996; Page 1996).

In the Australian context, recent work is revealing the role of non-monetary factors in coastal migration (e.g. Burnley 1996; O’Connor \& Stimson 1996; Stimson et al. 1996; Walmsley et al. 1998). Much of Australia's internal migration to the North Coast of New South Wales, for example, has more to do with environmental and lifestyle factors than with employment (Stimson et al. 1996; Walmsley et al. 1998). In the Walmsley et al. (1998, p. 114) study, for instance, the top three ranked factors in migrant decision making were 'more pleasant climate', 'more relaxed lifestyle' and 'attractive physical environment'; 'improved job opportunities' was ranked seventh. These studies show the importance of lifestyle and place or region-specific factors in shaping patterns of rural change. They also partly address the call by Marsden et al. (1996, p. 361) for theoretical and methodological approaches that 'examine the differential constitution of "structural" processes, their articulation in localities, and the role of actors' to help explain processes of rural change.

In an attempt to address this new agenda, this paper focuses on the role of local actors in creating and defining new economic and cultural landscapes in the Denmark Shire in the south-west of Western Australia (Figure 1). The Shire has evolved from a small, predominantly dairying area in the 1970 s to a highly sought-after location with an increasingly diverse local economy. In part, this transformation reflects the economic and lifestyle interests of a range of migrant groups to the Shire over the past 25 years, as well as diversification amongst established farmers in response to depressed commodity prices. Denmark's in-migrants have varied from 'cashed out' 1970s alternative lifestylers ('hippies') and early retirees to the recent arrival of wealthy metropolitan investors seeking to 'cash in' on the 'cashed out' society. It is these recent groups and their role in processes of change in the district that are the focus of this paper.

It is argued that a revaluing of the rural and cultural landscape of Denmark is occurring whereby a cultural landscape partly created by 1970s/1980s waves of alternative lifestyle groups and early retirees is now increasingly being commodified and marketed by investors in the Shire. In developing our argument we draw on Giddens' (1984) theory of structuration to show how local agency interacts with structural determinants of change to shape the particularities of change at the local level. In structuration theory, structures are not seen as immutable, as in conventional structuralist approaches, but are both a medium and an outcome of social practices. This 'duality of structure' allows for both the reproduction and transformation of structures from the 'unintended consequences' resulting from the collective outcome of the actions of many individuals. The significance of structuration theory for our study is that we can begin to see how the in-migration of alternative lifestylers in the 1970s created new and/or altered economic and cultural spaces. The 'unintended consequences' resulting from the collective outcome of the actions of many individuals seeking an independent lifestyle removed from the excesses of capitalism and consumerism have produced, ironically, a much valued and sought-after commodity. It is 


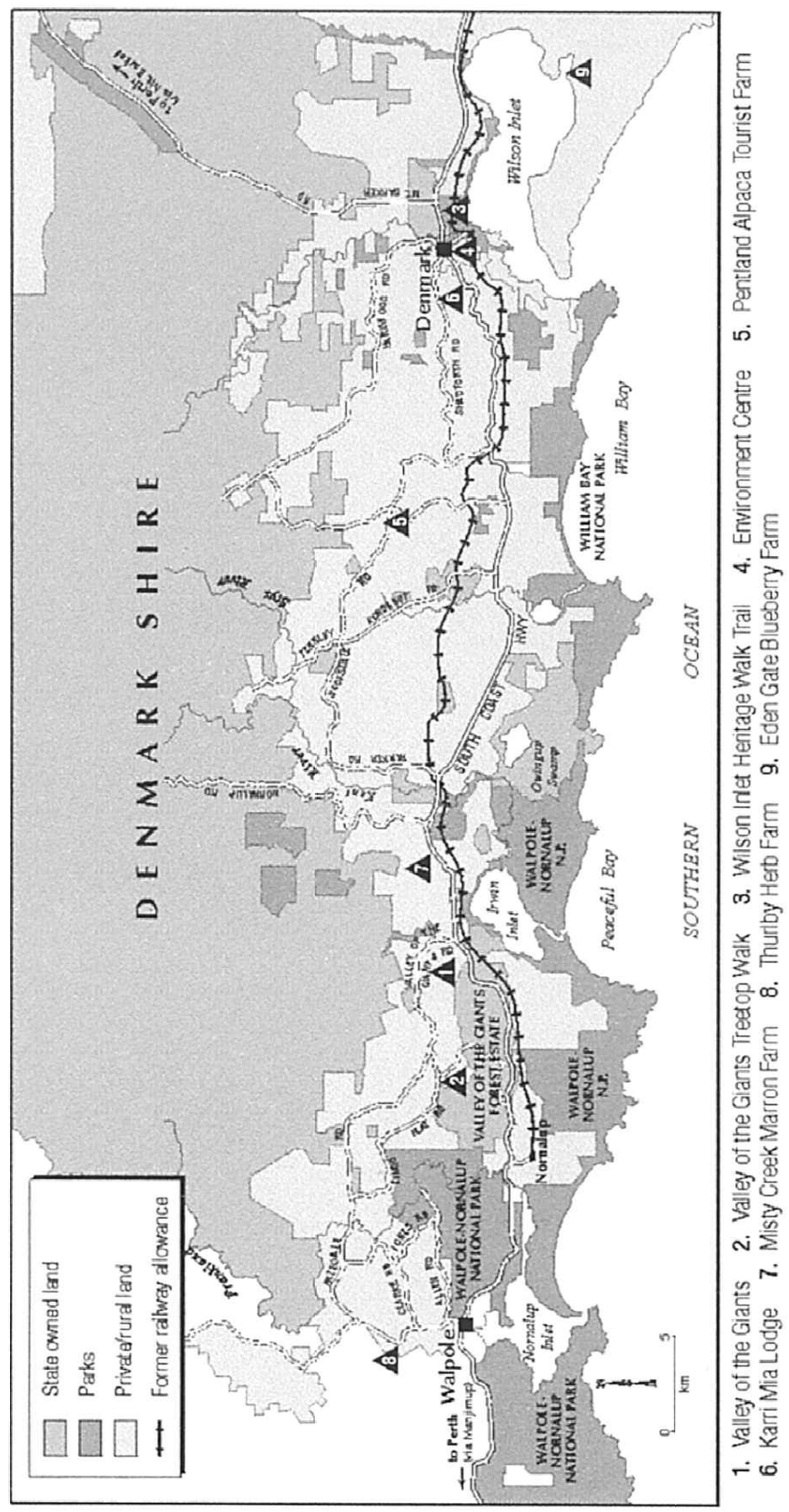

 
with this notion of agency in mind that we assess the roles of in-migrants from the mid-1970s onwards in revitalising and transforming the district. First, however, we provide a brief description of the methods and study site.

\section{Methods}

Thirty-five qualitative interviews were conducted during three fieldtrips to Denmark between 1996 and 1998. Initially, formal structured interviews were conducted with key individuals in the community, including the Denmark Shire Clerk, the Shire Planner, real estate agents, business owners, representatives from a range of community groups, and staff of the Denmark Tourist Bureau. We relied partly on 'snow-balling' techniques for the identification and selection of in-migrants to interview. The key personnel formally interviewed assisted with directing us to long-term and recent migrants to Denmark who we interviewed using open-ended, in-depth interviewing techniques. Two major groups omitted from this study were Denmark property owners residing in Perth and migrants who, having settled in the district, subsequently decided to leave. While the inclusion of these groups in the study would have contributed substantially to the interview data, time and other constraints prevented us from exploring this avenue for the present study.

Secondary data sources included tourist brochures and accommodation registers held by Denmark Tourist Bureau, local employment trading system (LETS) statistics for March 1997, Shire of Denmark Rate Book data for 1996-97, Shire of Denmark Tree Plantation register, data held by the State Valuer General and the records of the Denmark Historical Society.

\section{Study site}

The township of Denmark was established in 1895 when the Millars Brothers established a sawmill near the present town site. The gold rush of the 1890s and early 1900s fuelled the growth of the colony/state thus increasing demand for timber, with a consequent rise in Denmark's population to 2000 in the early years of the twentieth century (Conochie 1990). However, Denmark's boom was brief as accessible timber reserves were rapidly depleted, culminating in the closure of the Millars Brothers mill in 1905. The state government purchased the town and infrastructure from Millars Brothers and remaining residents began to develop fruit and vegetable farms, fisheries and, from 1911, a dairy industry to service the distant goldfields. Most of these operations were small scale and marginal because of the remoteness of the area, remnant areas of dense forest and cobalt-deficient soils.

Denmark's population was boosted significantly in the inter-war period when Premier Mitchell instigated the Group Settlement Scheme, whereby groups of about 20 families, mainly from Britain, but also from Western Australia, were settled in camps at various locations throughout the south-west (Gabbedy 1988; Selwood et al. 1996; Brunger \& Selwood 1997). Fifteen groups with a total population of 1500 settlers were established in the Denmark district, a region with a 1911 population of only 500 . However, the Group Settlement initiative was as short lived as the earlier timber milling venture. The amount and quality of land allocated to settlers was inadequate, and most settlers accumulated significant debts when butter prices fell following the stock market crash of 1929 (Roberts 1944). The vast majority walked off their farms, abandoning them to the banks (Bolton 1994). Much of this alienated land was later amalgamated 
into larger, more viable holdings, particularly for dairying, which became the economic mainstay of the district until the 1970s.

By the mid-1970s the dairy industry began to decline following Britain's entry to the EEC, and the Shire's population once again contracted. The population was static at 1780 between 1971 and 1976, but rose to 2647 by 1986 with the arrival in the district of early retirees and alternative lifestylers ('hippies'). In 1991 the population had reached 2970 and by 1996 almost 3500 people were living in the Shire (ABS Census Data). The Shire's population is now estimated at 4400 (Statistics in Brief: Denmark Shire 1999). Most of the population increase is attributable to in-migration. According to the 1996 census, 36.7 per cent of Denmark Shire residents had resided in a different Statistical Local Area at the 1991 census, the majority from other Statistical Local Areas in Western Australia. ${ }^{1}$ Consequently, the composition of Denmark's population is much more heterogeneous than in the past, with the population characterised by disparate social and economic groups.

Accompanying the demographic shifts has been a profound transformation of the agricultural base of the Shire. For example, between 1971 and 1991 the size of the dairy herd declined by 84.4 per cent (Woolhouse 1995, p. 9), and land classified by the ABS as 'farmland' fell by 23 per cent to 34997 ha (calculated from ABS Agricultural data cited in Woolhouse 1995, p. 9). While some of this reduction in 'farmland' may reflect small farmers' increased reliance on off-farm incomes and semi-retirement, part is attributable to the growth of non-agricultural and new rural land uses. Thus 'traditional' agriculture is now giving way to a more diverse range of rural land uses. Shire staff are aware of this process: as the Shire Clerk remarked, 'while the town still sees itself as a farming town, it is not farming in the traditional sense'.

A prime example of the process of agricultural transformation is the rapid expansion of vineyards and wineries in the district. In 1995 there were only four wineries in the district (Selwood et al. 1996), but by 1999 there were eight wineries and 16 vineyards. Denmark Tourist Bureau now promotes 'The Wine Lovers' Guide to Denmark' and organised wine tours are available. Commercial tree planting, especially Tasmanian Blue Gum (Eucalyptus globulus), is another new venture which is expanding in the region (Figure 2). Other farming initiatives include herb, blueberry and Chinese chestnut cultivation, a meadery, llamas, rabbits, deer, ostrich and emu production, and a developing wildflower industry (Woolhouse 1995, 1996; Selwood et al. 1996). Many of these new rural land uses have a symbiotic relationship with the growing tourism industry. Frequently, the new agricultural enterprises are tourist attractions in themselves and many are reliant, to some degree, on visitors' fees and/or the purchase of produce by tourists. These activities exist alongside a growing number of art and craft studios in the district, which also cater to the tourist trade.

\section{In-migration and rural change}

Like many other scenic coastal areas of Australia, Denmark became a popular destination for people seeking a relaxed lifestyle with little engagement with the formal economy. The process began in the mid-1970s with the in-migration of two major groups of people: rural retreaters/early retirees and communards, the latter group having very diverse socio-economic characteristics. More recent in-migrants have tended to be wealthier than the 1970s and 1980s groups, and many are investors and/or land speculators.

Insights into the demographic characteristics of in-migrants can be gained by tracking 


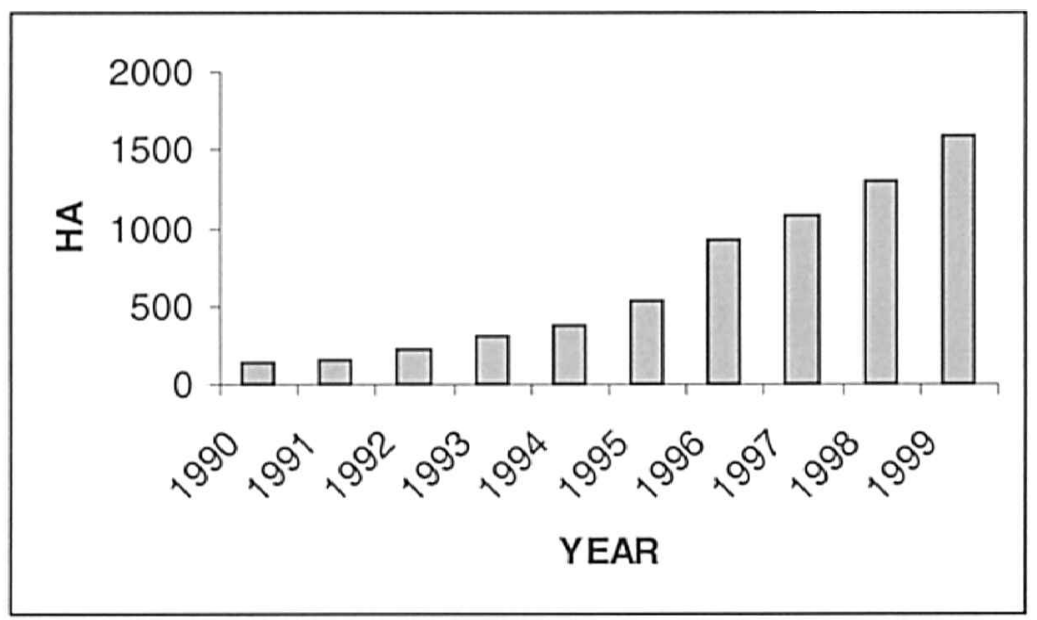

FIGURE 2. Cumulative totals of annual plantings of Tasmanian Bluegum in Denmark Shire since 1990. Source: data held by Denmark Shire.

the absolute numbers in 5 year age cohorts in one census as they move into the next age cohort at the following census (Table 1). The cohort that was aged 25-29 at the 1986 census increased by 34.4 per cent over 5 years to 1991 (which became the 30-34 age cohort in the 1991 census). The second largest proportional increase over 5 years to 1991 was the 55-59 cohort, which grew by 29.8 per cent. The net in-migration in these two cohorts represents, respectively, the influx of young alternative lifestylers and middle-aged rural retreaters/early retirees.

The influx of young alternative lifestylers continued between 1991 and 1996 together with a substantial increase in the number of children that were aged 0-4 at the 1991 census. Similarly, the numbers of people belonging to the $45-49$ and 50-54 cohorts at the 1991 census increased significantly in the 5 years to 1996 . The stabilisation of the number of people who were in the 55-59 age cohort at the 1991 census is more difficult to explain. It may reflect the out-migration of older long-term residents of Denmark who are capitalising on the Shire's rapidly rising land and house prices by selling up and moving elsewhere (Shire Clerk, pers. comm.).

There has also been significant change in Denmark's employment structure (Table

TABLE 1. Percentage change in 5 years in the numbers of individuals in selected age cohorts in the 1986 and 1991 censuses

\begin{tabular}{ccccccc}
\hline $\begin{array}{c}\text { Age } \\
\text { cohort }\end{array}$ & $\begin{array}{c}\text { Nos in 1986 } \\
\text { census }\end{array}$ & $\begin{array}{c}\text { Growth in 1986 } \\
\text { cohorts after 5 } \\
\text { years (\%) }\end{array}$ & Rank & $\begin{array}{c}\text { Nos in 1991 } \\
\text { census }\end{array}$ & $\begin{array}{c}\text { Growth in 1991 } \\
\text { cohorts after 5 } \\
\text { years (\%) }\end{array}$ & Rank \\
\hline $0-4$ & 260 & 18.08 & 6 & 293 & 34.47 & 3 \\
$20-24$ & 149 & 24.83 & 3 & 132 & 38.64 & 2 \\
$25-29$ & 183 & 34.43 & 1 & 186 & 55.91 & 1 \\
$45-49$ & 146 & 20.55 & 5 & 162 & 31.48 & 4 \\
$50-54$ & 132 & 21.21 & 4 & 176 & 27.84 & 5 \\
$55-59$ & 141 & 29.79 & 2 & 160 & 0.63 & 9 \\
\hline
\end{tabular}


TABLE 2. Changes in absolute numbers by employment category between 1986 and 1996

\begin{tabular}{lccc}
\hline Employment category & $\begin{array}{c}\text { Employed at 1996 } \\
\text { census (\%) }\end{array}$ & $\begin{array}{c}\text { Employment gain/loss } \\
\text { 1986-96 (No. of } \\
\text { individuals) }\end{array}$ & Rank \\
\hline Agriculture, forestry and fishing & 21.06 & -1 & 12 \\
Mining & 0.24 & -6 & 14 \\
Manufacturing & 4.97 & -33 & 15 \\
Electricity, gas and water supply & 0.24 & -1 & 12 \\
Construction & 8.91 & 42 & 5 \\
Wholesale trade & 3.47 & 25 & 9 \\
Retail trade & 11.44 & 47 & 3 \\
Accommodation, cafés and restaurants & 7.41 & 51 & 2 \\
Transport and storage & 2.52 & 14 & 10 \\
Communication services & 1.1 & 3 & 11 \\
Finance and insurance & 1.66 & 65 & 13 \\
Property and business services & 7.49 & 3 & 11 \\
Government administration and defence & 2.92 & 45 & 4 \\
Education & 11.42 & 34 & 7 \\
Health and community services & 7.65 & 39 & 8 \\
Cultural and recreational services & 3.71 & 26 & \\
Personal and other services & 3.79 & & \\
\hline
\end{tabular}

2). Between 1986 and 1996 the largest absolute growth in employment was in 'property and business services', followed by 'accommodation, cafés and restaurants' and 'retail trade'. The substantial increase in the numbers of people employed in these categories partly reflects the different lifestyle and economic interests of new settlers in the district as well as the influence of external economic pressures, particularly on conventional farming.

\section{Rural retreaters/early retirees}

For the rural retreaters/early retirees of the 1970s their move into the district was largely facilitated by the low price of rural holdings due to the collapse of the dairy industry. Also, some members of this group were 'cashing-out' using redundancy and/or superannuation payouts to acquire modest and less busy lifestyles. Low-priced, abandoned Group Settlement farmsteads, some with basic accommodation, provided opportunities to invest in and experiment with a wide range of innovative and specialist farming activities like hobby farms, horticulture and tourism-related ventures such as farmstay, rural chalets and bed and breakfast accommodation. The lure of cheap land, the promise of an idyllic rural lifestyle and the possibility of generating a modest income were important considerations for this group.

For many of this group, however, the reality did not match the ideal, and most struggled to earn a living after purchasing a property. Interviewees amongst this group (the 'stayers') said that they had underestimated the difficulties and hardships in becoming established, and they learned by trial and error. Some early retirees fell for the real estate line of how easy it would be to establish a rural lifestyle. One couple recalled a real estate agent's comment when they were looking for a property to buy in the mid-1970s: 'all you need to do is plant the trees and sit back and wait for the harvest'. The reality of hard work and the need for off-farm income to finance capital investments, especially in horticultural activities, led some to sell. 
Similar to some other Australian coastal towns, Denmark continues to attract early retirees. But, because of rising land prices, more recent arrivals are generally wealthier than their 1970s counterparts. In common with their 1970s predecessors, they, at least initially, seek a more relaxed lifestyle away from the city, and many claim not to be profit maximisers. One 'retired' couple, for example, who recently purchased a small camping/chalet resort on the shores of Wilson Inlet, realise that they could increase their turnover substantially by building more chalets, clearing more camping sites and extending their season (they are fully booked over the summer period). However, like many other people we interviewed, they prefer to forego the extra income to preserve their relatively relaxed lifestyle.

Some individuals from this group, however, do expand their businesses significantly to become full-time operators. These people see opportunities for business growth, often related to the growing tourism industry, and the temptation to expand becomes irresistible. They may begin with a few acres and subsequently decide to purchase a larger property of 100 acres or more to undertake some intensive agricultural activity like horticulture, viticulture, marron farming, emu production, or intensive grazing. In doing so, they are diversifying the district's rural and leisure activities, thus contributing to the creation of a new rural geography in the Shire.

\section{Alternative groups}

Alternative lifestyle groups ('hippies') formed another major component of this 1970s in-flow. As with the early retirees, and in common with alternative lifestylers who settled in parts of northern New South Wales (e.g. in the Nimbin, Lismore and Bellingen regions of northern New South Wales), the collapse of the dairy industry provided opportunities to acquire cheap land and rents. The small size of the properties (based on the old Group Settlement sub-divisions), and their low prices, also enabled alternative lifestylers to experiment with communal forms of living.

Members of this group were part of a wider counter-culture movement that emerged in the late 1960s and early 1970s out of the anti-Vietnam War movement. ${ }^{3}$ They held a strong environmental ethos, rejected materialism, consumerism and related values associated with post-war, capitalist industrial society (Birrell 1987). Similar to alternative groups that settled in other parts of rural Australia around this time, these new arrivals in Denmark saw their move as a retreat from the excesses of capitalism and consumerism. In Denmark they sought a self-sufficient, modest and environmentally sensitive rural lifestyle that has been characterised by communal living, low energy use house design and the adoption of 'natural' building materials such as mud-brick and, later, rammed earth.

Many initially planned to opt out of the formal economy for a self-sufficient lifestyle, but very few have been able to do so, and most are reliant to some extent on conventional ways of making a living. While many have remained in full-time or part-time employment, others moved into small-scale 'alternative' agricultural ventures such as permaculture and organic methods of horticultural production. More recently, some have entered the tourism industry by producing arts and crafts, opening studios/ craft shops, or offering farm stays and bed and breakfast accommodation. In their endeavours to earn an income the 'alternatives' commenced a process of agricultural and economic diversification which also added new dimensions to the Shire's economic and cultural landscape.

After settling in the district, communards began challenging existing land-use prac- 
tices and zoning and building regulations. One of their more contentious actions was to press the council for special rural sub-divisions to allow multiple occupancy. Initially, these applications were vigorously opposed by the council, but their eventual approval in the late 1970 s on appeal to the State Planning minister set a precedent which made it easier for subsequent settlers to do likewise. This has resulted in a diverse range of communal types of housing developments in the Shire.

Through time they also became an increasingly articulate voice in the community as they began to challenge accepted and long-held attitudes towards the forests and other natural resources. For instance, they formed the first vocal opposition to logging in the surrounding Karri forest by emphasising its environmental and aesthetic values. Their most notable success was in 1987 when the government rejected a second woodchip industry on the south coast (Schur 1988, p. 21). The event was influential in promoting greater environmental awareness amongst the Denmark community, and was indicative of an ongoing revaluation of the district's rural landscape instigated largely by these newcomers. Some long-established residents claimed that the rejection of the woodchip licence would 'kill' the town, but the forests have since become a tourism asset for the district. Protection of the environment remains an important issue for the early alternatives, and presently they are beginning to exert greater influence at the local political level through well-organised environmental campaigns and forest protests, and by seeking seats on the council.

Since the late 1980s these earlier alternative groups have been joined by a new wave of younger alternatives, the 'new hippies' or 'ferals', who are perhaps the most marginal group of recent settlers because they lack the resources of earlier settlers. ${ }^{4}$ Many are seasonal migrants moving north in winter to places like Broome and their numbers in Denmark peak at around 200 in summer (local environmental activist, pers. comm.). They are part of the emergence of a new global phenomenon of environmentally-based social movements constituting a new wave of resistance to globalisation, science and technological dominance over nature, which they see as leading to a global environmental crisis. The permaculture and environmental movements provide them with important social networks of contacts and a shared system of beliefs and values. Presently, they are at the forefront of ongoing and lengthy forest blockades (forest rescue camps) to end logging of old-growth forests in the south-west of Western Australia. ${ }^{5}$ Some would argue that they are more radical but less hedonistic than earlier alternative groups.

To date, their links with the established Denmark community have been limited, and, like Nimbin's 'ferals' (Constine 1995, p. 82), certain sections of Denmark's establishment use them as scapegoats for the Shire's social problems. However, some more established alternatives have sought to integrate them into the local community by welcoming their involvement in local environmental groups and other community and environmental projects. Many have joined the relatively successful Local Employment Trading System (LETS), started in 1989, which has helped draw them into the community. ${ }^{6}$ Also, their growing presence in town on market days in summer has added a certain festive flavour and ambience to the occasion. Together with the established alternatives at the market they offer a range of alternative goods and services such as arts and crafts, entertainments like juggling and music, New Age therapies, massage and fortune telling, thereby adding tourism value to the market and town. Their material contributions to the formal economy are perhaps small, but their physical presence and their volunteer contributions lend character to the community.

The alternatives are diverse in terms of lifestyles, socio-economic backgrounds and 
degree of integration with the greater Denmark community and with the formal economy (Selwood et al. 1998). At one extreme are highly organised groups of formerly middle-class urban dwellers who purchased property on which they constructed either shared houses or groups of houses (Conochie 1995). At the other extreme are the recent alternatives, the 'ferals', who tend to be more transient and marginal, inhabiting informal settlements relatively remote from towns and major roads. To survive, they rely in part upon government welfare, assistance from those sympathetic to their life choices, intermittent work on permaculture and organic farms, and casual sales of arts, crafts and LETS services.

The modest lifestyles, cultural and environmental activities, and the low-key economic initiatives of these various groups have helped create considerable cultural capital within the district and have increased the district's economic potential in several ways. The successes of the alternative groups in conserving remnant areas of forest have, for example, helped retain much of the district's natural attraction, and the forests have become a key element of the Shire's burgeoning nature-based tourism industry. For example, the Department of Conservation and Land Management's Tree Top Walk near Walpole, an elevated walkway through Tingle forest, attracts over 200000 visitors a year (Howard Manning, District CALM Officer, Walpole, pers. comm.). Indeed, to some extent, the uniqueness of the Karri and Tingle forest and its restricted geographical range provides the district with a competitive advantage when attracting residents, tourists, and urban capital. Also, the endeavours of the first alternative lifestylers to earn an income, when the utopian dream of a self-sufficient lifestyle proved largely unattainable, commenced a process of agricultural and economic diversification usually in ways that raised the tourism potential of the region. Moreover, in developing livelihoods, these settlers tended to eschew highly technical and environmentally deleterious methods of agricultural production, opting instead for small-scale alternative and environmentally sensitive businesses aimed at generating a target income rather than profit maximisation. Denmark is now perceived as a district possessing a certain cultural ambience and rural charm, where life is easier and less competitive. This emerging image of Denmark as a rural idyll has encouraged further growth and in-migration leading to increased development pressures and escalating land prices. Metropolitan investors are now seeking to 'cash in' on the district's very marketable rurality, cultural ambience and attractive natural environment.

\section{Investors}

During the 1990s, investment levels in the Shire increased significantly when wealthy business investors and land speculators began to 'discover' Denmark. Some are investing in relatively large-scale business ventures such as extensive tree plantations, wineries, resort developments and other tourist-related ventures, while others are making speculative investments in land. This trend towards larger investors moving into the district has been recognised by local real estate agents who, as one estate agent put it, 'are not your mums and dads setting up a family business', but astute, highly skilled and successful business people.

An appreciation of the extent of this 'cashing-in' trend can be gained by examining the growth in property investment and land speculation in the Shire over the past few years. For example, between 1993 and 1997 there was a 27 per cent increase in the number of rateable properties and a doubling of the rateable values over a 3 year period (Table 3). The increase in the number of rateable properties is due in part to the 
TABLE 3. Numbers and values of rateable properties in the Denmark Shire

\begin{tabular}{lcc}
\hline Year & No. of rateable properties & Rateable value $(\$ \mathrm{~m})$ \\
\hline $1993 / 94$ & 2517 & 54.4 \\
$1994 / 95$ & 2622 & 59.1 \\
$1995 / 96$ & 3122 & 68.2 \\
$1996 / 97$ & 3188 & 108.6 \\
Percentage change, 1993/94-1996/97 & 26.7 & 99.6 \\
\hline
\end{tabular}

creation of an additional 300 lots through sub-division of broad acreage into special rural plots rezoned or formally adopted under town planning schemes. A further 260 or so lots are currently awaiting council approval.

Data from the State Valuer General's Office and Shire Rate Book data provide additional evidence of speculative investment in the Shire. Between 1988 and 1997 vacant land in the town site rose in value at an annual rate of 66 per cent. Also, absentee owners now comprise 45 per cent of total property owners, with 25 per cent of rateable properties owned by non-residents from the Perth metropolitan region (Shire of Denmark Rate Book 1996-97; Selwood et al. 1995, p. 154). The real estate industry which has now 'discovered' Denmark is actively marketing property there to urban investors as a cheaper alternative to the more inflated prices in roughly equivalent country around Margaret River (Figure 3). ${ }^{7}$ These activities attest to the infusion of investment capital (much of it speculative) to the Shire and to the progressive commodification of the district's resources.

Interviewees from this group of urban investors who settled in Denmark indicated that they were investing in a lifestyle, while capitalising on Denmark's growth. They

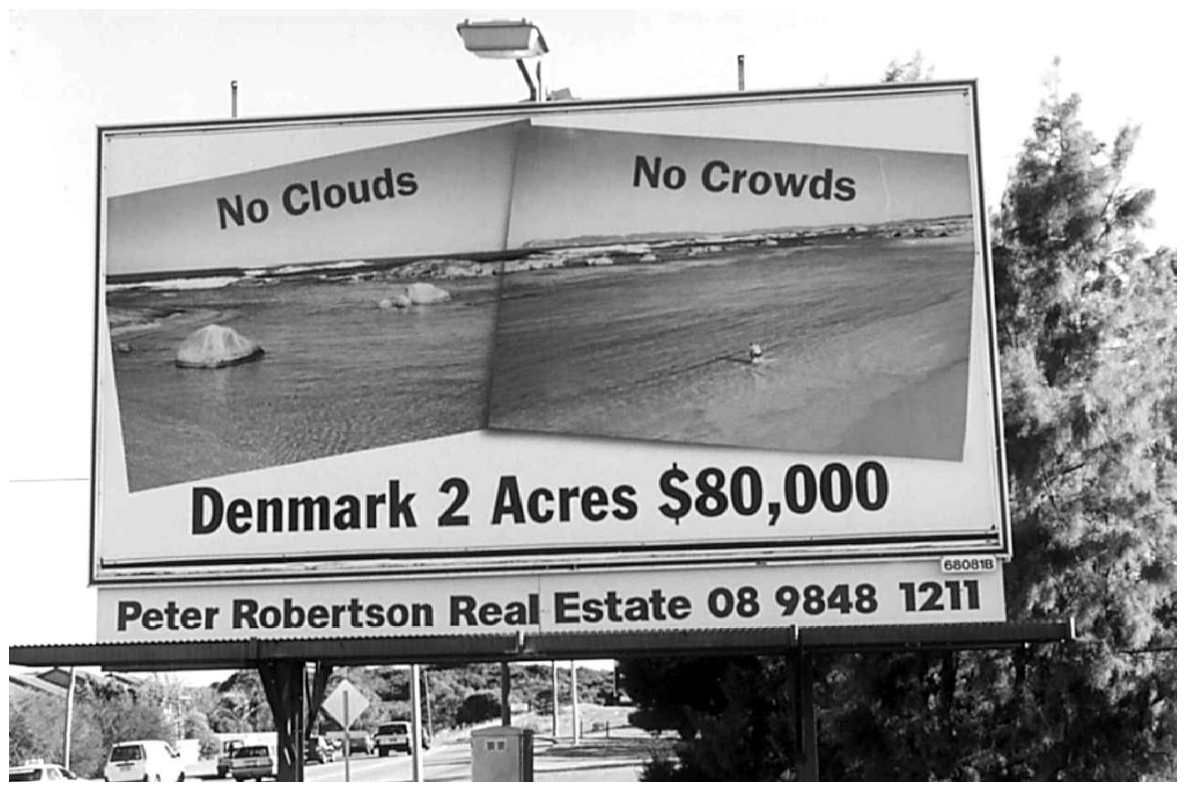

FIgure 3. A billboard advertisement on Stirling Highway, Cottesloe - one of Perth's affluent coastal suburbs. 
pointed out how land prices in Denmark in the early 1990s had been rising at a faster rate than in metropolitan Perth and mentioned the growing tourism potential of the district. They all identified Denmark as a location for investment with considerable growth potential. They also mentioned the district's environmental amenity, easy-going lifestyle and cultural ambience resulting from the presence of a large number of alternative lifestylers, as positive features influencing their decision to move there. One young financial sector worker, who telecommutes daily to his head office in Perth, sees himself and his partner as 'fringe' alternatives; while sharing some of the values and lifestyle characteristics of the alternatives, they remain firmly engaged in the formal economy and are making substantial investments in a winery and in tree plantations.

Thus the perception that the district has a store of cultural capital has been an important consideration for recent investors. For this latest wave of investors and speculators, the lifestyle and cultural landscape of Denmark are valuable and marketable commodities. Denmark is now heading 'up-market' as wealthy investors make their mark on the landscape. Increasingly, other professionals such as consultants, architects and accountants are moving in, able to telecommute to their city offices via the Internet. Thus, improvements in information technology are gradually enabling people to establish more urban-oriented work activities in a rural setting, resulting in notable changes in the socio-economic composition of the population and creating new demands and expectations of local residents.

In the township, local businesses are being upgraded and new enterprises are opening. The second-hand store now sells 'antiques and collectibles'; the grocery shop now offers locally produced organic fruit and vegetables; the bakery has been gentrified; and, the old butter factory that sold only local crafts has extended its range of stock to include seventeenth- and eighteenth-century French antiques. There is now a gourmet delicatessen and a growing number of restaurants featuring ethnic and local speciality cuisine. Wine, food and music festivals are now hosted throughout the year. These all form part of the attraction for the new wave of metropolitan investors who are further transforming the Shire as they carve out new economic and social spaces. However, these spaces entail increased commodification of both the township and rural landscape.

As the town moves 'up-market' and the growing tourism industry shifts from low-key, small-scale locally run and managed enterprises to larger and externally financed ventures, Denmark's new rurality and differentiated landscape is increasingly being oriented to a new tourist elite. For example, the Karri Mia Resort, the first large-scale, internationally marketed resort-style development in Denmark, sells the district in its brochures as a place where tourists can:

search out the local arts and crafts, dine at the wonderful restaurants ... and sample the local fruits, nuts and very fresh produce.... [or] just relax and unwind in the ambience orchestrated by nature's backdrop, birdsongs, black cows on green grass ...

Whilst the traditional image of the countryside (tranquillity and freshness) remains, it is increasingly being marketed with images of elite consumption and lifestyles (local art and eateries). Such promotions reflect not only the growing importance of elite consumption and the commodification of the landscape, but also reveal a new emerging image of Denmark. Moreover, this latest transformation bears witness to the evolving nature of the Denmark landscape into a marketable commodity that can be sold as a tourist or investment product. 


\section{Discussion and conclusion}

In common with other agricultural regions in Australia, Denmark has been affected by changes in the international economy (e.g. Epps \& Sorensen 1996; Grosvenor \& Wood 1996; Greive \& Tonts 1996). Since World War II, Australian farmers have responded to declining terms of trade by farm expansion, mechanisation and technical innovation, and in many rural areas this process continues. Denmark's rural sector responded similarly, often through extended family corporations and holdings (Brunger \& Selwood 1997). The 1970s collapse of the dairy industry, following Britain's entry to the EEC, created in Denmark a supply of relatively inexpensive land. Also, Australia's long boom was ending, ushering in a period marked by unemployment, redundancies and early retirement. This period coincided with broader societal changes such as the emergence of counter-culture movements of the late 1960s. The combination of these factors, as in parts of northern New South Wales, led the district to be settled by a range of alternative groups and early retirees. Thus began a process of economic and social diversification.

Denmark's rural landscape continues to become increasingly differentiated and commodified as rural space is revalued. Conventional farming practices characterised by large-scale production for distant markets remain important, but they are being augmented by a diverse range of generally small-scale producers for niche markets, often with on-site consumption related to the expanding tourism industry. Increasingly, the district is being marketed as a lifestyle for the consumption of tourists, and as an investment opportunity for Perth's affluent classes. As land values rise in response to this revaluing of the rural landscape, conventional farmers are adapting or leaving and other actors are moving in to take their place.

Some authors have interpreted similar rural change elsewhere as a shift from Fordist agricultural production for mass markets to a post-Fordist mode of flexible production and niche marketing (for a summary and critique see Page 1996), implying a direct causal link between the agricultural sector and international markets in capital, finance and commodities. However, such linkages are indirect and the transition/distinction is neither clear-cut nor universal. In select locations like Denmark, where a switch to post-Fordist agriculture could be said to be occurring, the process is driven not by factors intrinsic to the international conditions peculiar to agriculture, but by a process of incorporation of space within the investment orbit of Perth's affluent classes. Outliers of metropolitan investment like Denmark have specific physical and cultural attributes that make them attractive sites for such investment and settlement.

Whilst settlement of the district by 1970s alternative groups and early retirees was contingent upon the presence of certain structural conditions - availability of cheap land in an area of natural beauty, and the broader socio-economic conditions outlined above - local agency has also been an important dimension of Denmark's transformation. In the initial stages of rural transformation in Denmark, economic diversification and the concomitant differentiation of the landscape was driven largely by the lifestyle choices of these new settlers. Sometimes, changes were induced by direct confrontation in the form of challenging existing land-use planning, zoning, and building regulations, and by engaging in environmental protests to preserve the district's natural environment. However, the effect of local agency was also indirect involving what Giddens (1984) terms the 'unintended consequences' of the collective outcome of the actions of many individuals. In pursuing their lifestyles, which for the alternative groups was the pursuit of a rural utopia outside the mainstream and involving a rejection of the values 
of materialism, consumerism and individualism, the district became known for its lifestyle values and cultural ambience. Thus a new identity and rurality evolved, resulting in the creation of a distinct cultural capital in which lifestyle became a marketable commodity to be capitalised on by land speculators, wealthy investors and real estate agents wishing to 'cash in' on the 'cashed out' society. Land prices began rising rapidly, leading to an acceleration of the processes of agricultural diversification and the commodification of the landscape.

These wealthy investors and migrants see Denmark's rural space as a location for the consumption of a commodified rurality, and their lifestyles reflect this latest transformation. Elite consumption, typical of gentrified inner city areas, is coming to characterise the town with the establishment of up-market resorts, specialised antique dealers, gourmet foods and wines, and rural investments such as wineries that cater to a more wealthy clientele. These latest changes, therefore, reflect another major shift in the revaluing of Denmark's rural landscape, but one in which local agency has been a key component of the process.

Finally, there is a certain irony in the fact that the alternatives have not sought to commodify the district's resources for themselves, but to create a society based on communal living, an environmentally sensitive lifestyle apart from what they saw as the excesses of capitalist-style development. However, in the pursuit of their ideals, they have helped create a new rurality which has been progressively commodified by a wave of investors who are finding ways to capitalise on the marketability of local rural attributes and ambient lifestyles. The presence of alternative lifestylers in the pursuit of a rural utopian dream outside the mainstream and with limited links to the formal economy created a cultural capital, which, in combination with the physical beauty and natural attractions of the district, produced a highly marketable 'way of life'. As Denmark's reputation grows and real estate agents increasingly market the consumption value (the lifestyle) of the district to urban investors, the long-term local residents, early retirees and alternative groups are finding their options for buying into the district much more constrained. The range of lifestyle choices is increasingly being confined to the more affluent from metropolitan Perth. Whilst this process is contributing to the diversification of the Shire's economic base, it may also be undermining a way of life for the alternatives and others seeking lifestyles with little engagement with the formal economy.

\section{Acknowledgements}

We thank David Reynolds from Denmark Shire Office for providing data and Leon Robinson, Curtin Library, for assistance with library searches. We also appreciate the helpful comments of two referees. Finally, John Selwood acknowledges the support during his visits to Western Australia of the Department of Geography, University of Western Australia.

Correspondence: George Curry, School of Social Sciences, Curtin University of Technology, Perth WA 6845, Australia. E-mail: curryg@spectrum.curtin.edu.au

\section{NOTES}

[1] Absentee landowners may be either investors with no intention of settling in the district or people wishing to settle in the district at a later date. 
[2] Several long-established farmers have sold up and purchased larger farming properties in districts to the near north such as Plantagenet and Rocky Gully where land is cheaper and shire rates are lower.

[3] The movement crystallised when 10000 of them gathered for the Nimbin Aquarius Festival in 1973 (Metcalfe 1995, p. 39).

[4] While the term 'feral' is used locally by the broader Denmark community in reference to these recent alternative lifestylers in the district, it is by no means universally accepted by these migrants themselves. Some are proud of the label, while others amongst them reject it for its negative connotations.

[5] See Trigger (1999) for a discussion of the contrasting ideologies between environmental activists and forest industry workers in Western Australia.

[6] LETS, while offering conventional services such as professional services, education, trades, rentals, childcare and general labouring, is dominated by services that reflect the interests of the alternative groups that constitute its members (e.g. permaculture courses, fortune telling, aroma therapy and massage).

[7] The 1999 Yellow Pages for Denmark lists six real estate agents and only one bank.

\section{REFERENCES}

BirRelL, R. (1987) 'The social origin of Australia's conservation movement', fournal of Intercultural Studies 8, pp. 22-38.

Bolton, G. (1994) A fine country to starve in (2nd edition), University of Western Australia Press, Perth.

BRUnger, A. \& Selwood, J. (1997) 'Settlement and land alienation in Western Australia: the shire of Denmark', Fournal of Historical Geography 23, pp. 478-95.

Burnley, I. (1996) 'Migration, well-being and development in coastal New South Wales, 1976-1991', Australian Geographer 27, pp. 53-75.

Bryant, C.R., Russwurm, L.H. \& McLellan, A.G. (1982) The city's countryside: land and its management in the rural-urban fringe, Longman Group Limited, London.

Conochie, E. (1995) 'From communism to communalism', in Metcalfe, B. (ed.) From utopian dreaming to community reality, University of New South Wales Press, Sydney, pp. 170-86.

Conochie, I. (1990) Denmark: an outline history (2nd edition), Denmark Historical Society.

Constine, G. (1995) 'From a London slum to Nimbin's magic!', in Metcalfe, B. (ed.) From utopian dreaming to community reality, University of New South Wales Press, Sydney, pp. 74-83.

Coppock, J.T. (1977) Second homes: curse or blessing?, Pergamon Press, Oxford.

Dilley, R.S. (1993) 'Coping with cottage conversions into homes', in Ashton, B. (ed.) Managing growth and sustaining rural communities, Rural and Small Town Research and Studies Programme, Mount Allison University, Sackville N.B., pp. 63-8.

Epps, R. \& SoREnson, T. (1996) 'The nature of leadership in rural Australia: a case study of four Central Western Queensland Towns', in Lawrence, G., Lyons, K. \& Momtaz, S. (eds) Social change in rural Australia, Central Queensland University, Rockhampton, pp. 154-66.

FrEY, W.H. (1993) 'The new urban revival in the United States', Urban Studies 30, pp. 741-74.

Gabbedy, J.P. (1988) Group settlement, University of Western Australia Press, Perth.

Giddens, A. (1984) The constitution of society: outline of the theory of structuration, Polity Press, Cambridge.

Greive, S. \& Tonts, M. (1996) 'Regulation, land development and the contested countryside: reflections on Bridgetown, Western Australia', New Zealand Geographer 52, pp. 18-23.

Grosvenor, S. \& WoOD, L.J. (1996) 'Recent changes in the Tasmanian dairy industry', New Zealand Geographer 52, pp. 56-64.

HALFACREE, K. (1994) 'The importance of "the rural" in the constitution of counterurbanization: evidence from England in the 1980s', Sociologia Ruralis 34, pp. 164-89.

Hugo, G. (1994) 'The turnaround in Australia; some observations from the 1991 census', Australian Geographical Studies 25, pp. 1-17.

Hugo, G. \& SMAILES, S. (1985) 'Urban-rural migration in Australia: a process view of the turnaround', fournal of Rural Studies 1, pp. 11-30.

ILBERY, R. (ed.) (1997) The geography of rural change, Longman, London. 
MARSDEN, T. (1996) 'Rural geography trend report: the social and political bases of rural restructuring', Progress in Human Geography 20, pp. 246-58.

Marsden, T., Munton, R., Ward, N. \& Whatmore, S. (1996) 'Agricultural geography and the political economy approach: a review', Economic Geography 72, pp. 361-75.

MCKenzIE, F. (1994) Regional population decline in Australia. Impacts and policy implications, Bureau of Immigration and Research, Canberra.

Metcalfe, B. (ed.) (1995) From utopian dreaming to community reality, University of New South Wales Press, Sydney.

Murdoch, J. \& MARSDEN, T. (1994) Reconstituting rurality: class, community and power in the development process, UCL Press, London.

O'Connor, K. \& STIMson, R.J. (1996) 'Convergence and divergence of demographic and economic trends', in Newton, P.W. \& Bell, M. (eds) Population shift, Australian Government Publishing Service, Canberra, pp. 108-25.

PAGE, B. (1996) 'Across the Great Divide: agriculture and industrial geography', Economic Geography 72, pp. 376-94.

Roberts, R.P. (1944) 'A study of land settlement in two areas of the extreme South West of Western Australia', Fournal of the Agriculture Department of Western Australia 211, pp. 171-96.

SANT, M. \& Simons, P. (1993) 'The conceptual basis of counterurbanisation: critique and development', Australian Geographical Studies 31, pp. 113-26.

Schur, B. (1988) 'Pro-active conservation: moves to rehabilitate the Denmark River Catchment, in Newman, P., Neville, S. \& Duxbury, L. (eds) Case studies in environmental hope, Environmental Protection Authority, Perth, pp. 19-27.

Selwood, J., Curry, G. \& Jones, R. (1996) 'From the turnaround to the backlash: tourism and rural change in the Shire of Denmark, Western Australia', Urban Policy and Research 14, pp. 215-25.

Selwood, J., Curry, G. \& Koczberski, G. (1995) 'Structure and change in a local holiday resort, Peaceful Bay on the southern coast of Western Australia', Urban Policy and Research 13, pp. 151-9.

Selwood, J., Curry, G. \& Koczberski, G. (1998) 'Financiers, "ferals" and rural sustainability in the Shire of Denmark, Western Australia', in Epps, R. (ed.) Sustaining rural systems in the context of global change, Proceedings of the joint IGU Commission for the Sustainability of Rural Systems and Land Use/Cover Change Study Group Conference, Armidale, Australia, 5-12 July 1997, Department of Geography, Planning, Archaeology and Palaeoanthropology, University of New England, Armidale, pp. 346-56.

Stadel, C. \& Selwood, J. (1996) 'Suburbia in the countryside: cottages and cottage dwellers in Canada', in Steineck, A. (ed.) Stadt und Wirtschaftsraum, Institut fuer Geographie der Technischen Universitaet Berlin, Berlin, pp. 311-24.

Stimson, R.J., Minnery, J.R., Kabamba, A. \& Moon, B. (1996) 'Sun belt' migration decisions: a study of the Gold Coast, Australian Government Publishing Service, Canberra.

TRIGGER, D. (1999) 'Nature, work and "the environment": contesting sentiments and identities in the Southwest of Western Australia', Australian fournal of Anthropology 10, pp. 163-76.

Walmsley, D.J., Epps, W.R. \& Duncan, C.J. (1998) 'Migration to the New South Wales north coast 1986-1991 - lifestyle motivated counterurbanisation', Geoforum 29, pp. 105-18.

Woolhouse, S.M. (1995) 'Traditional agriculture in Denmark, WA - another dinosaur?', unpublished paper presented at the Ninth International Conference of Historical Geographers, Perth, WA.

Woolhouse, S.M. (1996) 'Agriculture in Denmark, WA', unpublished paper presented at the Institute of British Geographers/Royal Geographical Society, Strathclyde, January 1996. 